\title{
Bacterial Endotoxin Induces Changes in the Organization and Expression of Actin and Modulation of the Cell Membrane of Microglia
}

\author{
Ebtesam Abd-El-Basset \\ Department of Anatomy, Faculty of Medicine, Kuwait University, Kuwait
}

\section{Key Words}

Ameboid microglia - Cytoskeleton - Actin • Scanning electron microscopy

\begin{abstract}
Background and Objectives: In situ there are at least three morphologically and functionally different forms of microglia: the resting, the activated, and the phagocytic microglia. The signals promoting the morphological changes which adapt microglia to specific functions are still unknown. In this study the effect of bacterial wall lipopolysaccharide (LPS) on the morphology and organization and expression of actin in microglia was investigated. In addition, the changes in the appearance of the cell membrane were investigated. Methods: Microglia cultures were prepared from neopallia of new-
\end{abstract}

\begin{tabular}{ll}
\hline KARGER & ( ) 2000 S. Karger AG, Basel \\
1011-7571/00/0092-0081\$17.50/0 \\
$\begin{array}{l}\text { Fax +4161306 1234 } \\
\begin{array}{l}\text { E-Mail karger@karger.ch } \\
\text { www.karger.com }\end{array}\end{array}$ & $\begin{array}{l}\text { Accessible online at: } \\
\text { www.karger.com/journals/mpp }\end{array}$
\end{tabular}

born mice and treated with LPS. Scanning electron microscopy, labeling with phalloidin, and immunoblotting were used. Results: The majority of nontreated microglia were ameboid in shape with many short processes that extended into lamellipodia. When microglia were treated with LPS most of the microglia acquired a large, round, and flat shape. The rest of the ameboid microglia became larger in size. Fluorescent labeling with phalloidin showed that the F-actin network appeared diffusely arranged throughout the cytoplasm of nontreated microglia. In LPStreated microglia the F-actin network was reorganized into filamentous bundles extending into microspike-like projections. Using scanning electron microscopy, the nontreated microglia had large membrane folds and few large blebs. In LPS-treated microglia most of the membrane folds and blebs at the
Dr. Ebtesam M. Abd-El-Basset, MD, PhD

Department of Anatomy, Faculty of Medicine, Kuwait University PO Box 24923, 13100 Safat (Kuwait)

Tel. +965 5312300, ext. 6033, Fax +965 5319478

E-Mail ebtesam@hsc.kuniv.edu.kw 
cell periphery disappeared with the appearance of many microspike-like projections. Immunoblotting showed that LPS-treated microglia upregulated their actin protein. Conclusions: These changes in the organization of F-actin and the cell membrane may reflect adaptation of activated microglia to specific functional activity, such as increases in their phagocytic activity.

Copyright $\odot 2000$ S. Karger AG, Basel

\section{Introduction}

Microglia play an active role in the steady state and injury of the central nervous system (CNS) and in neurodegenerative diseases [14]. It has been suggested that in situ there are at least three forms of microglia, i.e., the resting, the activated and the phagocytic microglia, each having different shape and each representing a different functional state [5, 6]. Resting microglia have most commonly small oval cell bodies with numerous highly branching, thin processes [7, 8]. Two forms of microglia appear after exposure of the CNS to injury, the activated or reactive microglia and the phagocytic or ameboid microglia [6]. The reactive microglia are small round cells with processes which are shorter and stutter than the resting microglia [9]. The ameboid microglia have a larger, irregularly shaped cell body with lamellipodia but lacking the branching process [10]. The signals promoting the morphological changes which adapt microglia to specific functions are still unknown.

In cultures bacterial wall lipopolysaccharide (LPS), a potent inflammatory agent, stimulates microglia to secrete a number of trophic factors including interleukin (IL-1), IL-8, prostaglandin $\mathrm{E}_{2}$, tumor necrosis factor$\alpha(\mathrm{TNF}-\alpha)$, and neurotrophins [11-16]. It also activates the production of phagocytosis-related enzymes and superoxide anions [17] and induces dramatic morphological changes. In the presence of LPS microglia become large, flat, and round cells $[17,18]$. These changes in cell morphology and cell activity are accompanied by changes in cell motility and in the organization of different cytoskeletal proteins $[19,20]$. It was suggested that changes in the organization of actin filaments result in modulation of the cell membrane.

This study investigates the effect of LPS on the appearance to the membrane of microglia growing in tissue culture, using scanning electron microscopy with attempts to establish whether any changes in the pattern and distribution of F-actin relate to membrane modulation. In addition, this study investigates if the changes in the organization of F-actin reflect an actual difference in the relative amount of actin.

\section{Materials and Methods}

\section{Microglia Cultures}

Neopallial cultures were prepared from newborn Balb/c mice as described previously [21]. The cerebral hemispheres were isolated aseptically and the meninges were removed. The neopallia were dissected out and then gently forced through a sterile $75-\mu \mathrm{m}$ Nitex mesh. The cells were suspended in modified Eagle's minimum essential medium (mMEM) containing $5 \%$ horse serum (HS). Aliquots of $5 \times 10^{6}$ nigrosine-excluding cells were plated in $75-\mathrm{cm}^{2}$ Falcon culture flasks and incubated at $37^{\circ} \mathrm{C}$ in a humidified atmosphere of $5 \% \mathrm{CO}_{2}$ in air for 10 days with change of medium every 2-3 days. At that stage the cells form a dense monolayer of GFAP-positive astroglia; the cultures were then incubated for an additional 12-16 days without medium change, to generate microglia which grew in medium progressively conditioned by astroglia. At days 22-26 clumped cells were washed out with Puck's balanced salt solution, leaving the newly formed microglia attached to the culture substratum. The microglia were then treated with $0.25 \%$ trypsin for $15 \mathrm{~min}$ and were plated on glass coverslips for immunofluorescence study and scanning electron microscopy.

Microglia cultures were treated for 5 days with $5 \mu \mathrm{g} / \mathrm{ml}$ LPS in mMEM containing 5\% HS. Microglia 
control cultures were incubated with MMEM containing $5 \% \mathrm{HS}$, but without LPS.

\section{Scanning Electron Microscopy}

The cells on the coverslips were fixed in 3\% glutaraldehyde for $2 \mathrm{~h}$ then postfixed in $1 \%$ osmium tetroxide for half an hour. The cells were then dehydrated in graded acetone followed by critical point drying. The cells were coated with gold and examined with a JSM6400 Scanning Electron Microscope.

\section{Reagents}

Mouse monoclonal antibody to actin (react with all actin isoforms), LPS from E. coli 0127:B8, and pure chicken gizzard actin were purchased from Sigma Chemical Co. (St. Louis, Mo., USA). Rhodamine phalloidin was purchased from Molecular Probes, Inc. (Eugene, Oreg., USA). Low molecular weight standards and chemicals for polyacrylamide gel electrophoresis (PAGE) and immunoblotting were purchased from Bio-Rad Laboratories Ltd. (Mississauga, Ont., Canada).

\section{Immunofluorescence}

The cells grown on glass coverslips were fixed for 10 min with $3.7 \%$ formaldehyde in phosphate-buffered saline (PBS), then washed 3 times in PBS. The fixed cells were then treated with rhodamine phalloidin diluted 1:20 in PBS for $1 \mathrm{~h}$. The staining was carried out at room temperature. The preparations

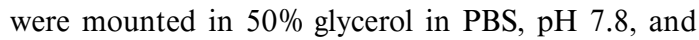
were examined with an Olympus photomicroscope equipped with a mercury vapor lamp, epifluorescence optics and appropriate interference filter.

\section{Polyacrylamide Gel Electrophoresis}

These experiments were done using three sets of microglia cultures. Each set had microglia treated for 5 days with $5 \mu \mathrm{g} / \mathrm{ml}$ LPS in mMEM with $5 \%$ HS and microglia grown in the same medium without LPS. The cells were washed 3 times in PBS, scraped off the culture flask with a rubber policeman and collected in PBS. The cells were immediately sonicated and the protein concentration was determined according to the method of Bradford [22]. The sonicated cells were dissolved in SDS containing sample buffer and boiled for $3 \mathrm{~min}$. The same amount of protein from each sample (30 $\mu \mathrm{g} /$ well) was analyzed electrophoretically in $10 \%$ SDS-PAGE gel according to the method of Laemmli [23]. Pure chicken gizzard actin ( $2 \mu \mathrm{g} / \mathrm{well})$ was used as a standard to determine the actin band on the gel. The gels were stained with $0.1 \%$ Coomassie blue.

\section{Immunoblotting}

The proteins in the gel were transferred to nitrocellulose sheets by a modification of the method of Towbin et al. [24]. After transfer, the nitrocellulose sheets were incubated for $1 \mathrm{~h}$ with $3 \%$ bovine serum albumin (BSA) in PBS. The nitrocellulose sheets were then incubated overnight at room temperature with mouse monoclonal antibody to actin diluted 1:500 in PBS containing 3\% BSA. The sheets were then incubated for $4 \mathrm{~h}$ with affinity-purified goat antimouse $\mathrm{IgG}$ conjugated to horseradish peroxidase diluted $1: 1,000$ in PBS containing 3\% BSA. The color was developed using freshly prepared $0.05 \%$ 4-chlor-1-naphthol and $0.015 \% \mathrm{H}_{2} \mathrm{O}_{2}$ in PBS. The reaction was stopped by washing in tap water. Immunoblots were scanned using the snapescan 1212 scanner and Adope Photoshop 5.0 program. The relative levels of actin expression were determined by analyzing the pixel intensity of the bands using an imaging analysis program (Image $\mathrm{J}$. version $1.04 \mathrm{~b}$, Wayne Rasband, NIH). The percentage of the protein expression was calculated in the following manner. The average background protein levels in the lane, excluding the bands, were first subtracted from both the control and treatment bands. Then, the average subsequent protein levels in the treatment and control bands were compared, and normalized to that of the control band. Polyacrylamide gel electrophoresis and immunoblotting experiments were repeated 3 times with each set of culture.

\section{Results}

\section{Morphology of Microglia in Cultures}

Microglia were isolated from dense neopallial cell cultures grown in astroglia-conditioned medium, as described previously [21]. The isolated microglia expressed CR3 receptors which bind Mac-1 antibody. Approximately $90 \%$ of microglia were ameboid cells with many short thick processes which expanded at their ends to form lamellipodia. The rest of the microglia in cultures were small and round in shape (fig. 1).

\section{Effect of LPS on the Morphology of Microglia}

After microglia were treated with $5 \mu \mathrm{g} / \mathrm{ml}$ of LPS in mMEM with 5\% HS for 5 days, 

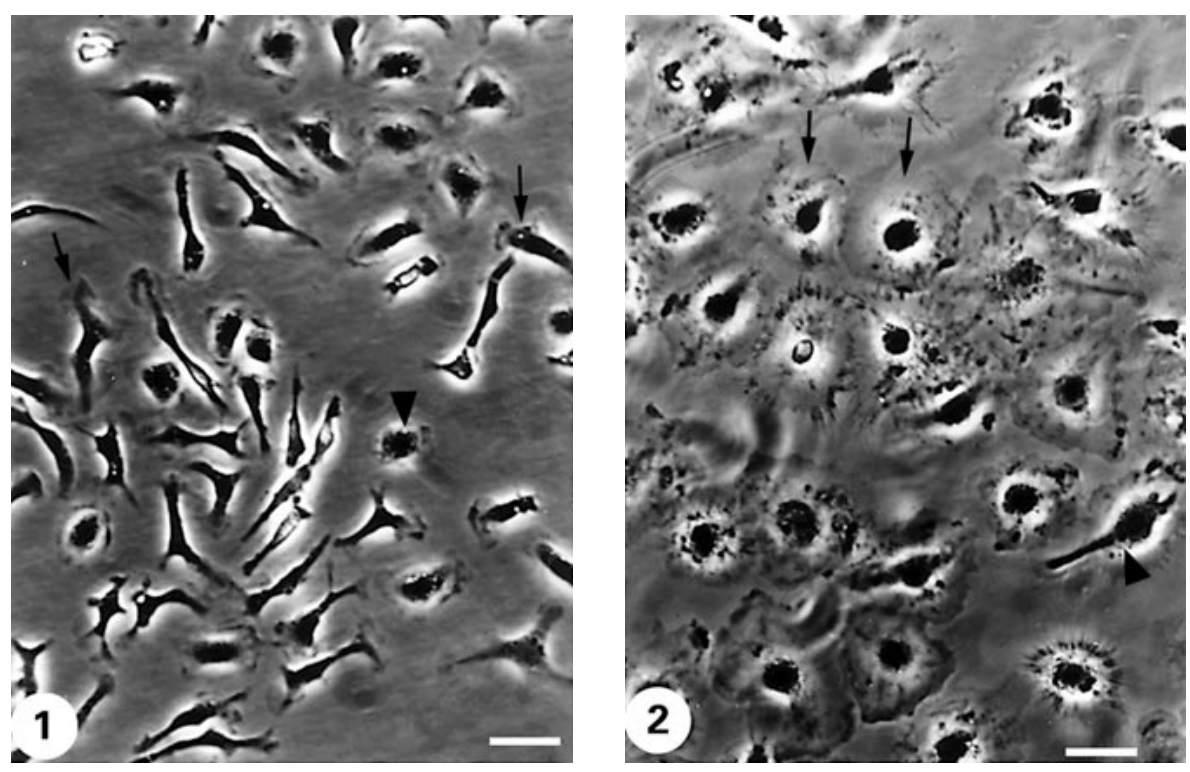

Fig. 1. Phase-contrast image of microglia culture before treatment with LPS showing that they have an ameboid shape with many short processes which expand at their ends to form lamellipodia (arrows). Few microglia are small and round in shape (arrowhead). Bar $=50 \mu \mathrm{m}$.

Fig. 2. Phase-contrast image of microglia culture treated with $5 \mu \mathrm{g} / \mathrm{ml}$ LPS in mMEM with $5 \%$ HS for 5 days showing that the majority of the cells become large, flat, round cells (arrows). Ameboid cells become larger (arrowhead). Bar $=50 \mu \mathrm{m}$.

about $65 \%$ of the cells assumed large, round, flat shape. The ameboid microglia with processes which did not transform into the round cells became larger with extended lamellipodia in different directions (fig. 2). In control cultures, where microglia were incubated in mMEM with 5\% HS and without LPS for 5 days, the ameboid microglia did not transform to large round flat cells, but they became smaller in size.

\section{F-Actin in Microglia}

F-actin network appeared granular and diffuse rather than filamentous in the cytoplasm of the cell body as well as in the processes of the ameboid microglia before treatment with
LPS. F-actin was more plentiful in the periphery of the lamellipodia (fig. 3). Stress fibers were not present in microglia.

\section{Effect of LPS on the Organization of \\ F-Actin in Microglia}

When microglia were treated with $5 \mu \mathrm{g} / \mathrm{ml}$ LPS for 5 days most of the F-actin isoform became reorganized by forming filamentous bundles that extended into numerous microspike-like projections at the cell periphery (fig. 4). Some of the ameboid microglia with processes also acquired microspike-like projections which contained also thick bundles of F-actin (not shown). In controls, in which microglia were incubated in mMEM with 5\% 

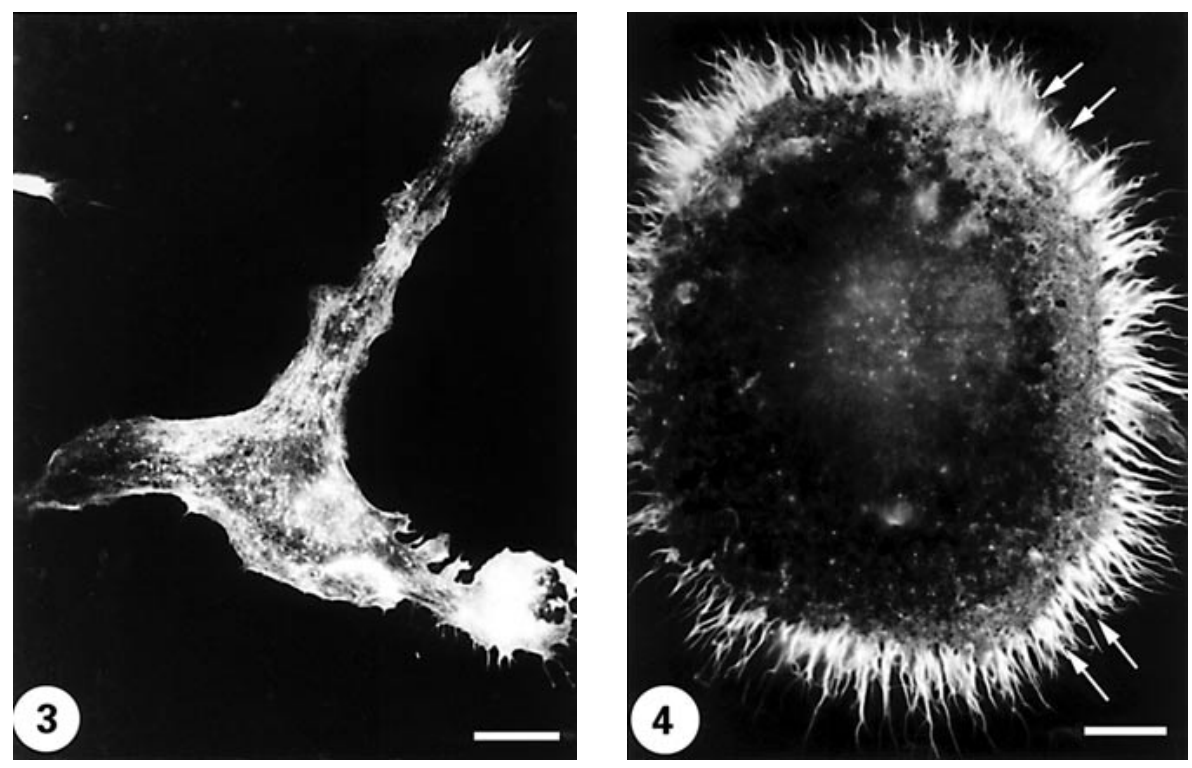

Fig. 3. Fluorescent image of microglia before treatment with LPS, labeled with rhodamine phalloidin, showing that the ameboid microglia have a network of F-actin which appears as granules rather than filaments. Bar $=10 \mu \mathrm{m}$.

Fig. 4. Fluorescent image of microglia treated with $5 \mu \mathrm{g} / \mathrm{ml}$ LPS in mMEM with $5 \%$ HS for 5 days labeled with rhodamine phalloidin showing thick bundles of F-actin in the microspikelike projections of large, round, flat cells (arrows). Bar $=10 \mu \mathrm{m}$.

HS without LPS, no changes in F-actin organization were observed (not shown).

\section{Scanning Electron Microscopy}

Using scanning electron microscopy, microglia grown in astroglia-conditioned medium (without treatment of LPS) and showing an ameboid appearance had few large membrane folds mainly in the cell body. They also had large membrane budding or blebs both in the cell body and proximal part of cell processes. At the distal end of the process the membrane expanded to form lamellipodia (fig. 5). The small round microglia had small microappendages extending at the cell periphery. Their cell bodies had many mem- brane folds and small blebs of different sizes (fig. 6).

When the microglia were treated with LPS for 5 days, the large round microglia had remarkable changes in the appearance of their membrane. They lost most of their membrane folds and showed membrane blebs of small size mainly in the cell center, whereas the cell periphery had no folds or blebs. The cells had many flat microspike-like projections that extended from the cell periphery (fig. 7). Microglia which did not transform to round cells had also microspike-like projections extending from the end of their processes and small membrane blebs in the proximal part of the cell processes (fig. 8). 

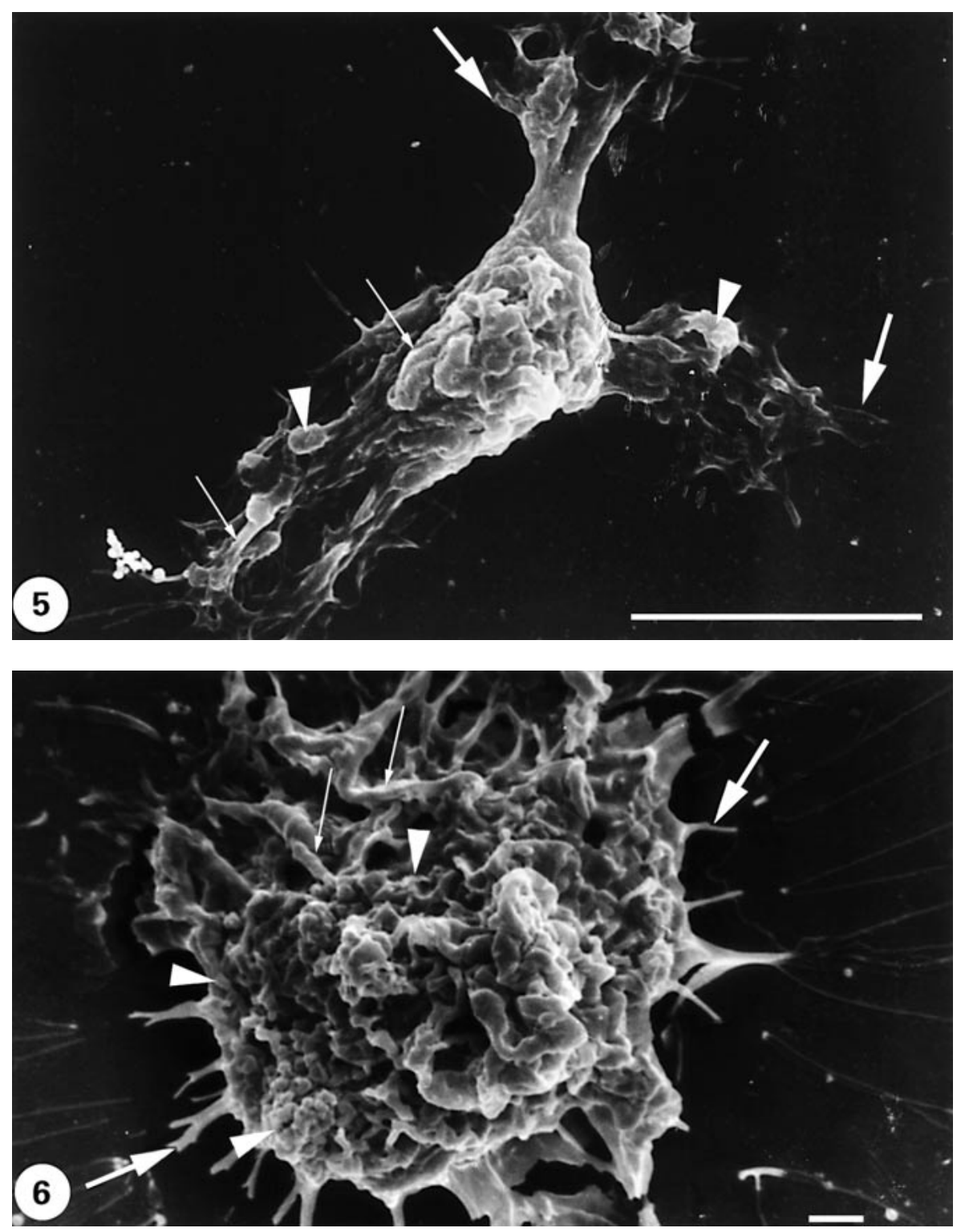

Fig. 5, 6. Scanning electron micrograph of microglia before treatment with LPS showing that the ameboid microglia (5) has many processes which expand into lamellipodia (large arrows). The surface of this cell shows few large membrane folds (small arrows) and blebs of large size (arrowheads). The small round cell (6) shows also large membrane folds (small arrows) and many blebs of different sizes (arrowheads) with microappendages at the cell periphery (large arrows). Bar in fig. $5=10 \mu \mathrm{m}$, in fig. $6=1 \mu \mathrm{m}$. 

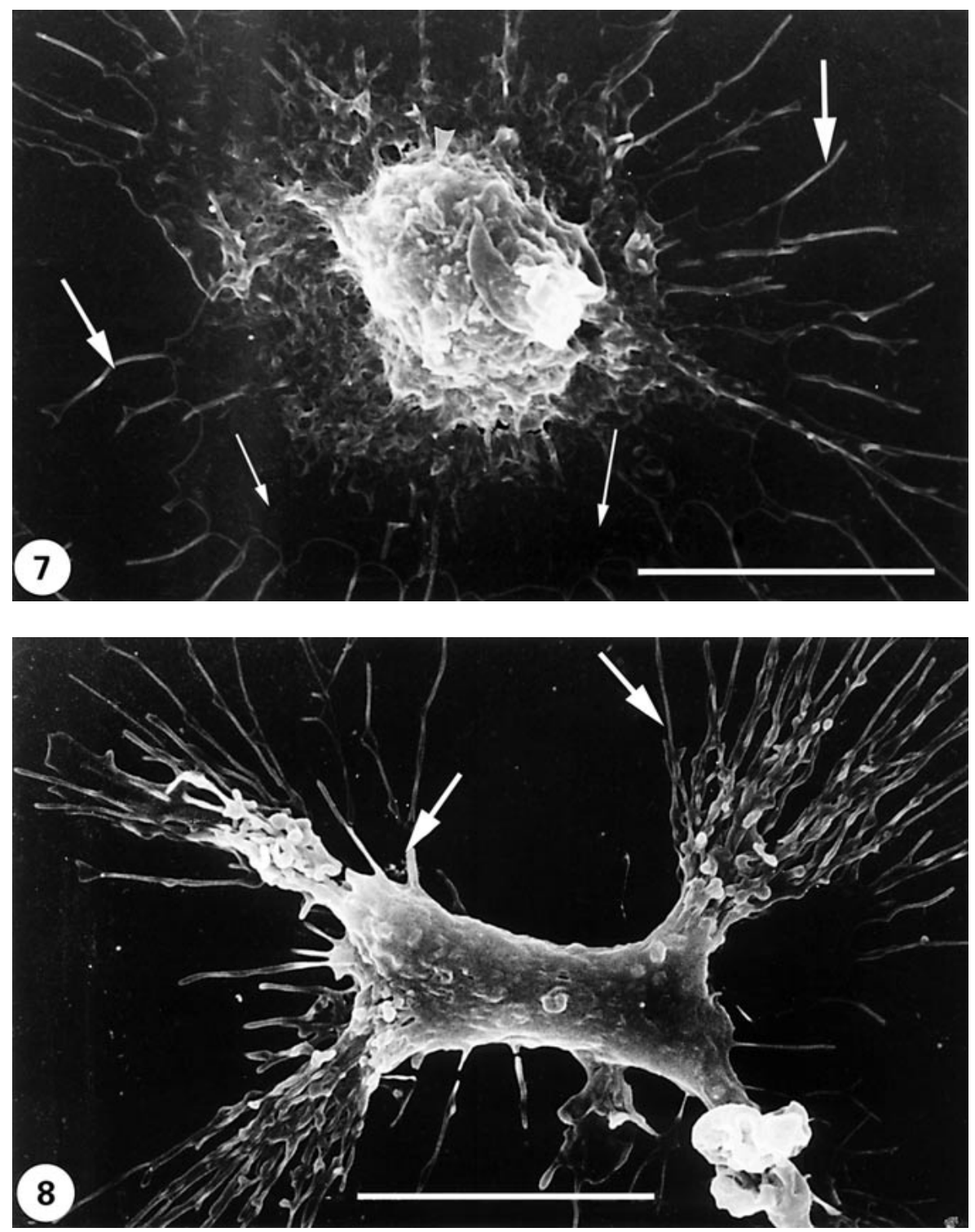

Fig. 7, 8. Scanning electron micrograph of microglia treated with $5 \mu \mathrm{g} / \mathrm{ml}$ LPS in mMEM with $5 \%$ HS for 5 days showing that the large, flat, round cell (7) has many microspike-like projections which appear at the cell periphery (large arrows) with disappearance of membrane folds at the periphery of the cell body (small arrows). The center of the cell shows many small membrane blebs (arrowhead). The ameboid cell (8) shows many microspike-like projections at the end of the processes (large arrows) with the presence of many small membrane blebs in the proximal part of the cell processes. Bar $=10 \mu \mathrm{m}$. 


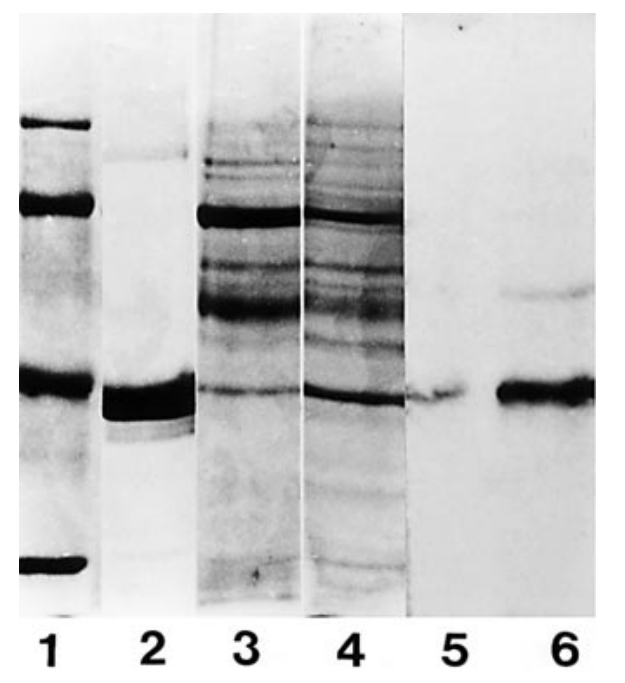

Fig. 9. 10\% SDS-PAGE gel stained with Coomassie blue (lanes 1, 2, 3, 4). Lane 1 = Low molecular weight standards; lane 2 = pure chicken gizzard actin; lane $3=$ protein from LPS-nontreated microglia culture; lane 4 $=$ proteins from microglia culture after treatment with $5 \mu \mathrm{g} / \mathrm{ml}$ LPS for 5 days. Nitrocellulose sheets of transferred protein similar to lane 3 (lane 5) and to lane 4 (lane 6), immunolabeled with antibody to actin (lanes 5,6 ), show the remarkable increase in the amount of actin in LPS-treated cells (lane 6).

\section{Immunoblotting}

Since LPS induced morphological changes in the microglia which were accompanied by changes in the organization of F-actin, we examined the changes in relative amounts of actin in untreated and LPS-treated whole microglia homogenates. The amount of actin expressed in LPS-stimulated microglia increased compare to the amount of actin expressed by nonstimulated microglia (fig. 9). Quantification of the Western blots showed that the actin level in treated cells increased to $320 \%$ of control. In addition, there were some stimulating and some inhibiting effects on a number of proteins which have not yet been identified.

\section{Discussion}

In normal cultures, before treatment with LPS, microglia have an ameboid morphology and many short, thick processes. They have no polarity; the process radiate from all sides of the cell. The morphology may be interpreted as somewhat intermediate between that of ameboid and ramified microglia in situ, indicating the metamorphic capacity of microglia. The diffuse organization of F-actin throughout the cytoplasm of normal microglia may account for the failure of normal microglia to have polarity.

Treating microglia with LPS causes dramatic morphological changes and reorganization of F-actin. Reorganization of the F-actin network into filamentous bundles extending into the microspike-like projections is associated with the disappearance of membrane folds and blebs from the periphery of the cell as observed by scanning electron microscopy. The organization of F-actin in the microglia before and after treatment of LPS can have a major influence on the behavior of the overlying plasma membrane. Actin filaments can push the plasma membrane outward to form long microspikes or sheetlike lamellipodia. These observations support the suggestion that F-actin would play a determinant role in the morphological changes of microglia. The significance of the morphological changes and reorganization of F-actin, which leads to modulation in the cell membrane of microglia under the effect of LPS, is difficult to interpret at present. However, it may help the microglia to increase their phagocytic activity. LPS stimulated the phagocytosis of IgG-coated sheep erythrocytes by microglia $[20,25]$.

LPS is a component of the outer membrane of most of the gram-negative bacteria. Many studies demonstrate the effect of LPS on macrophages. In response to LPS, macrophages activate genes responsible for cytokine 
synthesis. Cytokine gene expression and protein secretion are time- and dose-dependent, which includes IL-8, IL-1D, IL-la, IL-6, TNF$\alpha$ and GM-CSF [26]. Many effects of endotoxin on animal cells are secondary to the overproduction of these cytokines [27]. LPS also induces reorganization of microfilaments in macrophages [28]. It has been suggested that the changes in macrophage function are the result of a highly coordinated series of intracellular responses. The intracellular signals which have been demonstrated in LPS-stimulated macrophages include the breakdown of phosphatidylinositol [29], the activation of protein kinase $\mathrm{C}$ [30], the transcription, translation, myristoylation and phosphorylation of three proteins (40, 42 and $68 \mathrm{kD})$ which are substrates for protein kinase $\mathrm{C}[31,32]$ and elevation of the intracellular calcium concentration [29].

Little is known about the effect of LPS on microglia. LPS stimulates microglia to produce many trophic factors including CSF-1
[18], IL-1 [13], IL-8 [16] and neurotrophins $[14,15]$. This supports the notion that activated microglia, which appear in damaged CNS, exert a beneficial effect in posttraumatic CNS and enhance neurotic outgrowth [33, 34]. LPS also induces morphological changes in microglia and reorganization of different components of the cytoskeleton, which reflect on the cell motility [20, 35] and increase the phagocytic activity of microglia [25].

LPS has multiple and very complex effects on microglia in the CNS. It is important to understand the multiple effects of LPS on neural cells in order to devise effective therapy for the treatment of bacterial infection and septicemia in the CNS.

\section{Acknowledgments}

This work was supported by Kuwait University through grant MA037. I would like to thank Mrs. Jeena Prashanth and Mrs. Alice Prakash for their technical assistance.

\section{References}

1 Dickson DW, Lee SC, Mattiace LA, Yen SC, Brosnan C: Microglia and cytokines in neurological disease, with special references to AIDS and Alzheimer's disease. Glia 1993;7: 75-83.

2 Giulian D: Reactive glia as rivals in regulating neuronal survival. Glia 1993; 7:102-110.

3 McGeer PL, Kawamata T, Walker DG, Akiyama H, Tooyama I, McGeer E: Microglia in degenerative neurological disease. Glia 1993; 7:84-92.

4 Streit WJ: The role of microglia in brain injury. Neurotoxicology 1996 ; 17:671-578.

5 Jordan FL, Thomas WE: Brain macrophages: Questions of origin and interrelationship. Brain Res 1988; 13:165-178.

Effect of LPS on Actin and Cell

Membrane of Microglia
6 Streit WJ, Graeber MB, Kreutzberg GW: Functional plasticity of microglia: A review. Glia 1988;1:301307.

7 Perry VH, Gordon S: Macrophages and microglia in the nervous system. Trends Neurosci 1988;11:273-277.

8 Lawson LJ, Perry VH, Dri P, Gordon S: Heterogeneity in the distribution and morphology of microglia in the normal adult mouse brain. Neuroscience 1990;39:151-170.

9 Murabe Y, Ibata Y, Sano Y: Morphological studies on neuroglia. II. Response of glia cells to kainic acidinduced lesions. Cell Tissue Res 1981;216:569-580.

10 Tseng CY, Ling EA, Wong WC: Scanning electron microscopy of ameboid microglial cells in the transient cavum septum pellucidum in pre- and postnatal rats. J Anat 1983; 136:251-263.
11 Gebicke-Haerter PJ, Bauer J, Schobert A, Northoff H: Lipopolysaccharide-free conditions in primary astrocyte cultures allow growth and isolation of microglial cells. $\mathrm{J}$ Neurosci 1989;1:183-194.

12 Woodroofe MN, Sarna GS, Wadhwa M, Haynes GM, Loughlin AJ, Tinker A, Cuzner ML: Detection of IL-1 and IL-6 in adult rat brain, following mechanical injury, by in vivo microdialysis: Evidence of a role for microglial in cytokine production. $\mathbf{J}$ Neuroimmunol 1991;33:227.

13 Van Dam A, Brouns M, Louisse S, Berkenbosch F: Appearance of interleukin-1 in macrophages and in ramified microglia in the brain of endotoxin-treated rats: A pathway for the induction of non-specific symptoms of sickness? Brain Res 1992;588:291-196. 
14 Heese K, Fiebich BL, Bauer J, Otten $\mathrm{U}$ : NF-кB modulates lipopolysaccharide-induced microglial nerve growth factor expression. Glia 1998 ; 22:401-407.

15 Miwa T, Furukawa S, Nakajima K, Furukawa Y: Lipopolysaccharide enhances synthesis of brain-derived neurotrophic factor in cultured rat microglia. J Neurosci Res 1997;50: 1023-1029.

16 Ehrlich LC, Hu S, Sheng WS, Sutton RL, Rockswold GL, Peterson PK, Chao CC: Cytokine regulation of human microglial cell IL-8 production. J Immunol 1998;160:19441948.

17 Suzumura A, Marunouchi T, Yamamoto $\mathrm{H}$ : Morphological transformation of microglia in vitro. Brain Res 1991;545:301-306.

18 Fedoroff S, Hao C, Ahmed I, Guilbert LJ: Paracrine and autocrine signaling in regulation of microglia survival; in Fedoroff S, Juurlink BHJ, Doucette R (eds): Biology and $\mathrm{Pa}-$ thology of Astrocyte-Neuron Interactions. New York, Plenum Press, 1993, pp 247-262.

19 Bader MF, Taupenot L, Ulrich G, Aunis D, Ciesielski-Treska J: Bacterial endotoxin induces $(\mathrm{Ca} 2+) \mathrm{I}$ transients and changes the organization of actin in microglia. Glia 1994;11: 336-344.

20 Abd-El-Basset DM, Fedoroff S: Effect of bacterial wall lipopolysaccharide on morphology, motility, and cytoskeletal organization of microglia in cultures. J Neurosci Res 1995;41:222-237.
21 Hao C, Richardson A, Fedoroff S: Macrophage-like cells originate from neuroepithelium in culture: Characterization and properties of the macrophage-like cells. Int J Dev Neurosci 1991;9:1-14.

22 Bradford MM: A rapid and sensitive method for quantification of microgram quantities of protein utilizing the principles of protein dye binding. Anal Biochem 1976;72:248254.

23 Laemmli UK: Cleavage of structural proteins during the assembly of the head of bacteriophage T4. Nature 1970;227:680-685.

24 Towbin H, Staehelin T, Gordon T: Electrophoretic transfer of proteins from polyacrylamide gels to nitrocellulose sheets: Procedure and some applications. Proc Natl Acad Sci USA 1979;76:4350-4354.

25 Abd-El-Basset EM, Fedoroff S: Dynamic of actin filaments during Fcmediated phagocytosis. Acta Neuropathol 1994;88:527-537.

26 Zhong WW, Burke PA, Hand T, Walsh MJ, Hughes LA, Forse RA: Regulation of cytokine mRNA expression in lipopolysaccharide-stimulated human macrophages. Arch Surg 1993;128:158-164.

27 Morrison DC, Ryan JL: Endotoxins and disease mechanisms. Annu Rev Med 1987;38:417-432.

28 Shinji H, Kaiho S, Nakano T, Yoshida T: Regorganization of microfilaments in macrophages after LPS stimulation. Exp Cell Res 1991;193: 127-133.
29 Prpic V, Weisel JE, Somers SD, Diguiseppi J, Gonias SL, Hamilton TA, Herman B, Adams DO: Effects of bacterial lipopolysaccharide on the hydrolysis of phosphatidylinis stol-4,5 bisphosphate in murine peritoneal macrophages. J Immunol 1987;139:526-533.

30 Hamilton TA, Adams DO: Molecular mechanisms of signal transduction in macrophages. Immunol Today 1987;8:151-158.

31 Rosen A, Nairn AC, Greengard P, Cohn ZA, Aderem A: Bacterial lipopolysaccharide regulates the phosphorylation of the $68 \mathrm{k}$ protein $\mathrm{ki}$ nase $\mathrm{C}$ substrate in macrophages. $\mathrm{J}$ Biol Chem 1989;264:9118-9121.

32 Aderem A: The role of myristoylated protein kinase $C$ substrates intracellular signalling pathways in macrophages. Curr Top Microbiol Immunol 1992;181:189-207.

33 Rabchevsky AG, Streit WJ: Grafting of cultured microglial cells into the lesioned spinal cord of adult rats enhances neurite outgrowth. J Neurosci Res 1997;47:34-48.

34 Streit WJ, Walter SA, Pennell NA: Reactive microgliosis. Prog Neurobiol 1999;57:563-581.

35 Ciesielski-Treska J, Ulrich G, Aunis $\mathrm{D}$ : Protein kinase C-induced redistribution of the cytoskeleton and phosphorylation of vimentin in cultured brain macrophages. J Neurosci Res 1991;29:362-378. 